\title{
TRANSARTERIAL CHEMOEMBOLIZATION WITH DOXORUBICIN- ELUTING MICROSPHERES: SINGLE-CENTER REVIEW OF SAFETY PROFILE
}

\author{
Aušra Bankauskaite் ${ }^{1}$, Alvydas Česas ${ }^{2}$, Algimatas Šimkaitis ${ }^{3}$, Loreta Malinauskiene் $\dot{e}^{4}$ \\ ${ }^{1}$ Klaipeda University Hospital, Oncology Clinic, Head of Chemotherapy Day Care Department, \\ Lithuania, ${ }^{2}$ Klaipeda University Hospital, Head of Oncology Clinic, Lithuania, \\ ${ }^{3}$ Klaipeda University Hospital, Radiology Clinic, Head of Interventional Radiology Department, \\ Lithuania, ${ }^{4}$ Klaipeda University Hospital, Radiology Clinic, Lithuania
}

Key words: DEB-TACE, microspheres, chemoembolization, drug eluting bead.

\begin{abstract}
Summary
Background. Since 1977 when TACE was introduced for the first time it became a standard treatment for nonresectable $\mathrm{HCC}$ without vascular invasion or extrahepatic disease. TACE is also performed for other indications, such as colorectal metastases, cholangiocarcinoma, neuroendocrine tumors and etc. Material/methods. the evaluation of interventional therapy with DEB-TACE of 8 patients each with unrespectable $\mathrm{HCC}$, cholangiocarcinoma, neuroendocrine metastatic carcinoma. A comparison of therapy-associated complications performed.

Results. We analyzed results of DEB-TACE performed in our Hospital since 2014. DEB-TACE was technically successful in all patients. A total of 21 DEB-TACE procedure was performed in 8 patients during the 2-year period. Two patients $(20 \%)$ had five treatments, 1 patient (15\%) had four treatments, 4 patients $(50 \%)$ had two treatments and $1(15 \%)$ had one treatment. Pain, nausea, fever and fatigue were the most common side effects following DEBTACE, with a frequency of $76 \%, 33 \%, 57 \%$ and $71 \%$ respectively.

Conclusions. The current results show DEB-TACE to produce beneficial tumor response and to have exceptionally low complication rates.
\end{abstract}

\section{Introduction}

Dr. Yamada introduced transarterial chemoembolization in 1977. Method was used in treatment of hepatocellular carcinoma (HCC). 120 patients were treated and the findings were published in 1983 [1]. During conventional transarterial chemoembolization (cTACE) different chemotherapeutic agents are mixed with viscous carrier (lipidol) and delivered to the feeding artery of the tumor, followed by embolic agent. This causes high concentration of chemo agent in the tumor and ischemic necrosis due to embolization. However, lipidol releases chemo agent quickly and high systemic concentrations of drug are reached [2]. The solution of this problem is the use of drug-eluting microspheres. Procedure is called drug-eluting beads transarterial chemoembolization (DEB-TACE). It prolongs contact tome between cancer cells and chemo agent and prevents systemic drug toxicity. This method is currently used in the treatment of HCC, nonresectable cholangiocarcinoma, colorectal metastases and metastatic neuroendocrine tumors and etc. [3].

The aim of the study/methods: the evaluation of interventional therapy with DEB-TACE of 8 patients each with unrespectable $\mathrm{HCC}$, cholangiocarcinoma, neuroendocrine metastatic carcinoma. A comparison of therapy-associated complications performed.

\section{Materials and methods}

Indications and contraindications for treatment. TACE is current standard treatment for nonresectable HCC without vascular invasion or extrahepatic disease (Table 1) $[4,5]$. TACE is also performed for other indications, such as colorectal metastases, cholangiocarcinoma, neuroendocrine tumors and etc.

Pretreatment imaging. Contrast material enhanced computer tomography (CT) with triphasic acquisitions or magnetic resonance imaging (MRI) should be performed before every procedure to asses liver lesions (location, number and size). Total body CT should be performed in 
the case of metastases in the liver. Portal vein is better evaluated by CT scan [5].

Periprocedural care. Periprocedural care differs according local clinic practice and experience. All periprocedural medications, including antibiotics, pain medications, intra-arterial lidocaine, corticosteroids and proton-pump inhibitors are administered at the physician's discretion [6]. Hydration with intravenous administration of 150-300 $\mathrm{ml} / \mathrm{L}$ normal saline solution is essential before all other premedication. Though there is no definitive evidence of benefit, many centers recommend antibiotics prophylaxis to cover Gram-negative enteric pathogens for 3-7 days. In sphincter of Oddi has been disrupted in patients' medical history, antibiotics should be administered for 14 days [7]. Pain relievers, antiemetics should be continued as long as needed.

HCC. Hepatocellular carcinoma (HCC) is the fifth most common malignancy worldwide and the third most common cause of cancerrelated deaths [8]. TACE is recommended as standard of care for patients with nonresectable $\mathrm{HCC}$ without PV thrombosis or extrahepatic metastases [9]. A recent systematic review had collected sufficient data on the use of DEB-TACE in HCC patients to support its use as a safe and effective chemoembolic treatment in intermediate HCC patients, however, there still needs more strong evidence to support the its superiority over c-TACE [10]. Molecular biology studies have shown that the level of vascular endothelial growth factor (VEGF) usually increases locally and systemically after TACE treatment is performed, whereas sorafenib can inhibit the activity of VEGF receptors [11]. Thus, in recent years a large amount of studies have tried to combine sorafenib with TACE for patients with unresectable HCC, while the results were controversial [12]. Combination therapy may bring benefits for unresectable HCC patients in terms of TTP but not OS. Further well-designed randomized controlled studies are needed to confirm the efficacy of combination therapy [13].

Hepatic colorectal metastases. Colorectal cancer (CRC) remains one of the leading causes of cancer-related deaths worldwide. Synchronous or metachronous liver metastases can be present in almost half of all individuals diagnosed with CRC [14]. TACE has a long history and has led to better patient survival while permitting a good quality of life, and as a result has been introduced into the guidelines for primary liver cancer and is considered, and used worldwide, in the treatment of metastatic disease from neuroendocrine tumors and CRC [15]. TACE and DEBIRI have been proven safe and effective in salvage treatment of non-responsive liver metastases (LM) from CRC, and are more frequently used than in the past. The phase III trial provided evidence that infusion of DEBIRI offers superior survival with better quality of life when compared with the same chemotherapy administered intravenously [16].

Case report

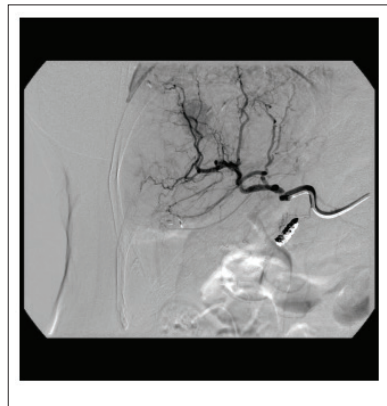

$$
\begin{gathered}
\text { Hipervascular } \\
\text { tumor seen before } \\
\text { embolization }
\end{gathered}
$$
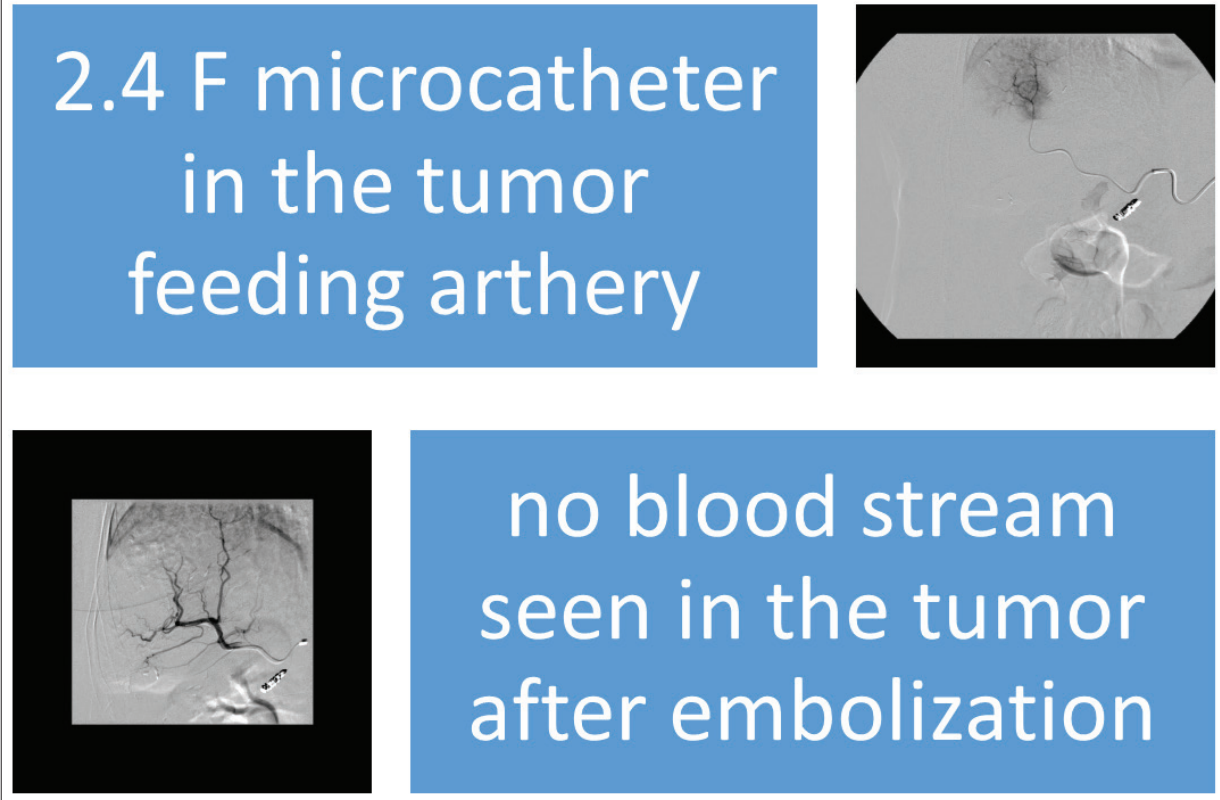

no blood stream

seen in the tumor after embolization 
Table 1. Indications and contraindications for TACE in HCC patients

\begin{tabular}{|c|c|c|}
\hline Indications & $\begin{array}{l}\text { Absolute contraindi- } \\
\text { cations }\end{array}$ & $\begin{array}{l}\text { Relative contraindi- } \\
\text { cations }\end{array}$ \\
\hline $\begin{array}{l}\text { Patients with confirmed dia- } \\
\text { gnosis of HCC }\end{array}$ & $\begin{array}{l}\text { Decompensated cir- } \\
\text { rhosis (Child-Pugh } \\
\text { score }>8 \text { ), jaundice, } \\
\text { encephalopathy or he- } \\
\text { patorenal syndrome }\end{array}$ & $\begin{array}{l}\text { Untreated esophage- } \\
\text { al varices at high risk } \\
\text { of bleeding }\end{array}$ \\
\hline No extrahepatic lesions & Main PV thrombosis & $\begin{array}{l}\text { Large tumor }(>10 \\
\mathrm{cm})\end{array}$ \\
\hline No main PV thrombosis & $\begin{array}{l}\text { Extensive tumor } \\
\text { involving both lobes } \\
\text { of liver }\end{array}$ & Severe comorbidities \\
\hline $\begin{array}{l}\text { Tumor involvement }>50 \% \text { of } \\
\text { the liver parenchyma }\end{array}$ & $\begin{array}{l}\text { Technical contrain- } \\
\text { dications, e.g. untre- } \\
\text { atable arteriovenous } \\
\text { fistula }\end{array}$ & $\begin{array}{l}\text { Incompetent papilla } \\
\text { with aerobilia }\end{array}$ \\
\hline $\begin{array}{l}\text { Patients with } \mathrm{HCC} \text { are not su- } \\
\text { itable for curative treatments } \\
\text { Disease recurrence after cura- } \\
\text { tive treatment } \\
\text { ECOG }<3 \\
\text { Good liver function (Child- } \\
\text { Pugh class A/B) } \\
\text { Serum creatinine }<177 \text { umol/L } \\
\text { Platelet count }>50.00 \text { cells/ } \\
\text { mm3 } \\
\text { Prothrombin activity }>50 \% \\
\text { WBC[3,000 cells } / \mathrm{mm} 3 \text {; neu- } \\
\text { trophils }[1,500 \text { cells } / \mathrm{mm} 3 \text {; left- } \\
\text { ventricular ejection fraction } \\
<50 \%\end{array}$ & $\begin{array}{l}\text { Creatinine clearance } \\
\qquad<30 \mathrm{ml} / \mathrm{min}\end{array}$ & Biliary dilatation \\
\hline
\end{tabular}

Table 2. Complications post DEB-TACE (21 procedure)

\begin{tabular}{|l|l|l|}
\hline Complication & $\begin{array}{l}\mathbf{7} \text { days after } \\
\text { procedure }\end{array}$ & $\begin{array}{l}\mathbf{1 4} \text { days after } \\
\text { procedure }\end{array}$ \\
\hline Pain & 16 & 1 \\
\hline Fatigue & 15 & 0 \\
\hline Nausea and vomiting & 12 & 0 \\
\hline Fever & 7 & 5 \\
\hline Cholangitis & 5 & 2 \\
\hline $\begin{array}{l}\text { Elevation of hepatic } \\
\text { transaminases }\end{array}$ & 10 & 3 \\
\hline pulmonary embolism & 0 & 1 \\
\hline
\end{tabular}

Neuroendocrine Hepatic Metastases. According to the 2010 WHO classification, NENs are divided into: well differentiated neuroendocrine neoplasm (NEN) G1 (mitotic count $<2$ per 10 high power fields (HPF) and/or $\leq 2 \% \mathrm{Ki} 67$ index), NEN G2 (mitotic count 2-20 per $10 \mathrm{HPF}$ and/or $3-20 \%$ Ki67 index), and poorly differentiated high grade malignant neoplasm (NEC) G3 (mitotic count $>20$ per 10 $116 \mathrm{HPF}$ and/or $>20 \% \mathrm{Ki} 67$ index) [17]. Metastatic involvement of the liver typically develops in about $46-93 \%$ of NEN patients. In $12.9 \%$ of these patients, metastases are already detectable at the time of initial tumor diagnosis and $5-10 \%$ of them present with metastases and primary of unknown origin [18]. c-TACE has been proven to be effective in symptom relief in $\leq 90 \%$ of patients, with long-term palliation being achieved with repeated c-TACE sessions, and a reported 5 -year survival of $\leq 83 \%$ [19]. There has been only one study on patients with liver metastases from these gastroenteropancreatic tumors. At 3-month follow-up, $80 \%$ of the 20 patients enrolled in the study had partial response, $15 \%$ had stable disease, and $5 \%$ had progressive disease [20]. TAE appears to be an optimal treatment approach for inoperable liver metastases from NENs, for higher metastatic load, for management of symptoms alone and in association with interferon or somatostatin analogues, suggesting a prolonged 5-yr survival and local tumor control and for survival improvement [21].

Treatment complications. As usually, all complications can be divided into the groups of immediate, periprocedural, long term complications. It also can be divided to minor and major complications. Postembolization syndrome does not count as complication by itself. It includes fever, pain, and increased white blood cell count [22]. Major complication are liver failure, postembolization syndrome requiring readmission or prolonged hospitalization, intrahepatic abscess, biloma requiring percutaneous drainage, gastrointestinal bleeding, iatrogenic dissection, death within 30 days [6,22].

Intraprocedural hepatic artery injury can be considered as immediate complication. It may only lead to reversible events, as artery spasm or inflammatory constriction. In severe cases it can cause dissection, thrombosis or formation of aneurism. However hepatic artery damage is more likely to occur in cirrhotic patients [23]. Periprocedural and longterm complications are probably related to metabolic impairment. Findings from liver function tests often worsen slightly after c-TACE, but the majority of studies have showed a return to baseline function within 1 week. However, a significant number of cases of hepatic failure have been reported. It was found that the dosage of chemotherapeutic agent, the basal bilirubin level, the basal prothrombin time, the basal AST level, and the stage of cirrhosis (Child's score) are significantly associated with the post-TACE increase in bilirubin. Patients with irreversible post-TACE hepatic decompensation present with significantly higher pre-TA$\mathrm{CE}$ bilirubin levels and longer prothrombin time in the dorsal and lateral surfaces of the left lobe, receive larger doses of drug, and have a more advanced stage of cirrhosis [24]. 
Reported complications of DEB-TACE include cholecystitis, liver abscess formation, tumor rupture, pancreatitis, pleural effusion, gastric ulcer bleeding, esophageal variceal bleeding, and spontaneous bacterial peritonitis. The list of complications of DEB-TACE is relatively shorter than that for c-TACE. This is mainly because the former technique is a relatively new procedure and is not practiced as widely as the latter one, but it could also be due to the lack of lipidol [25].

Our experience. In the period 2014 to 2016,8 patients were treated by DEB-TACE in our institution. 5 patients had confirmed HCC, 2 patients - metastatic neuroendocrine tumors and 1 patient - hepatic sarcoma. The therapeutic procedure was decided in an interdisciplinary tumor conference together with the visceral surgeons, interventional radiologists and medical oncologists. Median age of the patients at first TACE was 69 years (range, 38-79 years).

Preprocedure evaluation included review of medical history, physical examination, and laboratory studies for hematologic, hepatic, and renal functions. The imaging workup consisted of a baseline contrast-material enhanced CT or MRI within 1 month preceding the DEB-TACE procedure. Following the procedure, patients were followed at 4-8 weeks interval through clinical, laboratory, and imaging evaluation. Informed consent was obtained from all patients. All procedures were performed according to a standard protocol.

All patients were premedicated antacids (ranitidine) and pain relievers. Drug eluting microspheres were prepared using $100 \mu \mathrm{m}$-sized microspheres with doxorubicin dosage ranging from 75 to $150 \mathrm{mg}$ per session. Femoral arterial access was used in all patients. Celiac and/or superior mesenteric arteriography was performed to assess the arterial anatomy, vascular supply to the tumor, and patency of the portal vein. The lobar/segmental hepatic artery supplying the tumor was selectively cannulated with a microcatheter and embolized with drug-eluting microspheres. The end point for embolization was stasis of blood flow in the arterial feeders to the tumor. The decision for re-treatment was based on the absence of DEB-TACE contraindications and the sequential DEB-TACE procedures were performed within 2 weeks after documentation of response.

Patients were admitted for observation for 24-48 hours following the procedure. Prophylactic medications -against nausea (ondansetron IV), pain (hydromorphone) and intravascular hydration were administered during hospitalization.

DEB-TACE was technically successful in all patients. A total of 21 DEB-TACE procedure was performed in 8 patients during the 2 -year period. Two patients $(20 \%)$ had five treatments, 1 patient (15\%) had four treatments, 4 patients $(50 \%)$ had two treatments and $1(15 \%)$ had one treatment. Mean hospital stay after the procedure was 1.5 days (range 1-4 days).

Pain, nausea, fever and fatigue were the most common side effects following DEB-TACE, with a frequency of $76 \%, 33 \%, 57 \%$ and $71 \%$ respectively (Table 2 ). At 24 hours post-DEB-TACE, total bilirubin remained unchanged, whereas AST, ALT, and alkaline phosphatase showed significant increase. The values were classified according to the NCI-CTC version 3.0. At 1 month post DEB-TACE, six patients had normal liver function tests, 1 patients were in grade 1 and 1 patient in grade 2 of NCI v3 toxicity grading criteria. One patient had pulmonary embolism within 10 days after procedure. Cholangitis, requiring hospitalization, was observed in two patients within two weeks after procedure. No deaths within 30 days were observed.

\section{Conclusions}

The current results show DEB-TACE to produce beneficial tumor response and to have exceptionally low complication rates. The technique has the potential to become an effective alternative therapy or palliative measure in the treatment of hepatic malignancy.

\section{References}

1. Yamada R, Sato M, Kawabata M. et al. Hepatic artery embolization in 120 patients with unresectable hepatoma. Radiology 1983 ; 148:397-401.

http://dx.doi.org/10.1148/radiology.148.2.6306721

2. Pleguezuelo M, Marelli L, Misseri M. et al. TACE versus TAE as therapy for hepatocellular carcinoma. Expert Rev Anticancer Ther 2008; 8(10):1623-1641

http://dx.doi.org/10.1586/14737140.8.10.1623

3. Martin RC, Joshi J, Robbins K. et al. Hepatic intra-arterial injection of drug-eluting bead, irinotecan (DEBIRI), in unresectable colorectal liver metastases refractory to systemic chemotherapy: results of multiinstitutional study. Ann Surg Oncol 2011; 18(1):192-198. http://dx.doi.org/10.1245/s10434-010-1288-5

4. Bolondi L, Burroughs A, Dufour JF, Galle PR, Mazzaferro V, Piscaglia F. et al. Heterogeneity of patients with intermediate (BCLC B) Hepatocellular Carcinoma: proposal for a subclassification to facilitate treatment decisions. Semin Liver Dis 2012; 32:348-359.

5. Basile A, Carrafiello G, Ierardi AM. et al. Quality-improvement guidelines for hepatic transarterial Chemoembolization. Cardiovasc Intervent Radiol 2012.

http://dx.doi.org/10.1007/s00270-012-0423-z

6. Ryan JM, Ryan BM, Smith TP. Antibiotic prophylaxis in interventional radiology. J Vasc Interv Radiol 2004; 15:547-556. 
http://dx.doi.org/10.1097/01.RVI.000024942.58200.5E

7. Geschwind JF, Kaushik S, Ramsey DE. et al. Influence of a new prophylactic antibiotic therapy on the incidence of liver abscesses after chemoembolization treatment of liver tumors. J Vasc Interv Radiol 2002; 13:1 63-1166.

8. Faloppi L, Scartozzi M, Maccaroni E, Di Pietro Paolo M, Berardi R. et al. Evolving strategies for the treatment of hepatocellular carcinoma: from clinical-guided to molecularlytailored therapeutic options. Cancer treatment reviews 2011; 37: $169-177$. http://dx.doi.org/10.1016/j.ctrv.2010.08.001

9. Forner A, Reig ME, de Lope CR, Bruix J. Current strategy for staging and treatment: the BCLC update and future prospects. Seminars in liver disease 2010; 30: 61-74. http://dx.doi.org/10.1055/s-0030-1247133

10. Martin R, Geller D, Espat J, Kooby D, Sellars M. et al. Safety and efficacy of trans arterial chemoembolization with drugeluting beads in hepatocellular cancer: a systematic review. Hepato-gastroenterology 2012; 59: 255-260.

11. Li X, Feng GS, Zheng CS, Zhuo CK, Liu X. Expression of plasma vascular endothelial growth factor in patients with hepatocellular carcinoma and effect of transcatheter arterial chemoembolization therapy on plasma vascular endothelial growth factor level. World journal of gastroenterology: WJG 2004; 10:2878-2882.

http://dx.doi.org/10.3748/wjg.v10.119.2878

12. Muhammad A, Dhamija M, Vidyarthi G, Amodeo D, Boyd W. et al. Comparative effectiveness of traditional chemoembolization with or without sorafenib for hepatocellular carcinoma. World Journal of Hepatology 2013; 5: 364-371.

http://dx.doi.org/10.4254/wjh.v5.i7.364

13. Liu L, Chen H, Wang M, Zhao Y, Cai G. et al. Combination therapy of sorafenib and TACE for unresectable HCC: A Systematic Review and Meta-Analysis. PLoS ONE 2014; 9(3): e91124. http://dx.doi.org/10.1371/journal.pone.0091124

14. A. A. P. Slesser, P. Georgiou, G. Brown, S. Mudan, R. Goldin, and P. Tekkis. The tumour biology of synchronous and metachronous colorectal liver metastases: a systematic review, Clinical and Experimental Metastasis 2013; 30(4):457-470. http://dx.doi.org/10.1007/s10585-012-9551-8

15. Hong K, McBride J, Georgiades C, Reyes DK, Herman JM, Kamel IR and Geschwind JF: Salvage therapy for liver-dominant colorectal metastatic adenocarcinoma: comparison between transcatheter arterial chemoembolization versus yttrium-90 radioembolization. J Vasc Interv Radiol 2009; 20(3):360-367. http://dx.doi.org/10.1016/j.jvir.2008.11.019

16. Fiorentini G, Aliberti C, Tilli M, Mulazzani L, Graziano F, Giordani P, Mambrini A, Montagnani F, Alessandroni P, Catalano $\mathrm{V}$ and Coschiera P: Intra-arterial infusion of irinotecan-loaded drug-eluting beads (DEBIRI) versus intravenous therapy (FOLFIRI) for hepatic metastases from colorectal cancer: Final results of a phase III study. Anticancer Res 2012; 32: $1387-1396$.
17. Bosman FT: World Health Organization, and International Agency for Research on Cancer. In WHO classification of tumours of the digestive system, World Health Organization classification of tumours. 4th edition. Lyon:International Agency for Research on Cancer 2010:417.

18. Touzios JG, Kiely JM, Pitt SC, Rilling WS, Quebbeman EJ, Wilson SD, Pitt HA: Neuroendocrine hepatic metastases: does aggressive management improve survival?. Ann Surg 2005; 241(5):776-783. discussion 783-5.

19. Roche A, Girish BV, de Bae're T. et al. Trans-catheter arterial chemoembolization as first-line treatment for hepatic metastases from endocrine tumors. Eur Radiol 2003; 3(1):136-140.

20. de Baere T, Deschamps F, Teriitheau C. et al. Transarterial chemoembolization of liver metastases from well differentiated gastroenteropancreatic endocrine tumors with doxorubicineluting beads: preliminary results. J Vasc Interv Radiol 2008; 19:855-861.

http://dx.doi.org/10.1016/j.jvir.2008.01.030

21. Brown KT, Koh BY, Brody LA, Getrajdman GI, Susman J, Fong Y, Blumgart LH: Particle embolization of hepatic neuroendocrine metastases for control of pain and hormonal symptoms. J Vasc Interv Radiol 1999; 10(4):397-403.

http://dx.doi.org/10.1016/S1051-0443(99)70055-2

22. Brown DB, Cardella JF, Sacks D. et al. Quality improvement guidelines for transhepatic arterial chemoembolization, embolization, and chemotherapeutic infusion for hepatic malignancy. J Vasc Interv Radiol 2009; 20:219-226.

http://dx.doi.org/10.1016/j.jvir.2009.04.033

23. Sueyoshi E, Hayashida T, Sakamoto I. et al. Vascular complications of hepatic artery after transcatheter arterial chemoembolization in patients with hepatocellular carcinoma. Am J Roentgenol 2010; 195:245-251.

http://dx.doi.org/10.2214/AJR.08.2301

24. Chan AO, Yuen MF, Hui CK. et al. A prospective study regarding the complications of transcatheter intra-arterial lipiodol chemoembolization in patients with hepatocellular carcinoma. Cancer 2002; 94(6):1747-1752.

http://dx.doi.org/10.1002/cncr.10407

25. Brown DB, Fundakowski CE, Lisker-Melman M. et al. Comparison of MELD and Child-Pugh scores to predict survival after chemoembolization for hepatocellular carcinoma. J Vasc Interv Radiol 2004; 15:1209-1218.

http://dx.doi.org/10.1097/01.RVI.0000128123.04554.C1

\section{TRANSARTERINE CHEMOEMBOLIZACIJA NAUDOJANT DOKSORUBICINU IMPREGNUOTAS MIKROSFERAS: VIENOS GYDYMO ISTAIGOS PROCEDŪROS SAUGUMO ANALIZE்}

\section{A. Bankauskaitė, A. Česas, A. Šimkaitis, L. Malinauskienė}

Raktažodžiai: DEB-TACE, mikrosferos, chemoembolizacija, vaistais impregnuotos dalelès.

Santrauka

İvadas. Transarterinès chemoembolizacijos (TACE) procedūra 
pirmą kartą buvo aprašyta ir pradèta naudoti 1977 metais. Ji tapo standartu gydant pacientus, kuriems diagnozuota neoperabili kepenų ląstelių karcinoma (HCC). Ši procedūra taip pat taikoma gydant neoperabilius pakitimus kepenyse sergant cholangiokarcinoma, neuroendokrininiais navikais ir kt.

Tyrimo tikslas ir metodai. İvertinti procedūros saugumą gydant HCC, cholangiokarcinomą ir neuroendokrininius navikus taikant DEB-TACE. Apžvelgtos pagrindinès periprocedūrinès komplikacijos, jų dažnis.

Rezultatai. Atlikta duomenų apie DEB-TACE procedūrų, atliktų Klaipèdos universitetinèje ligoninèje nuo 2014 metų, analizè. Šiuo periodu gydymo įstaigoje gydymo metodas buva taikomas 8 pacientams ir iš viso atlikta 21 procedūra. Dviem pacientams
(20\%) buvo atliktos keturios procedūros, vienam pacientui (15\%) atliktos keturios procedūros, keturiems pacientams (50\%) atliktos dvi procedūros ir vienam pacientui $(15 \%)$ atlikta viena procedūra. Pagrindinès komplikacijos buvo skausmas $(76 \%)$, pykinimas $(33 \%)$, karščiavimas $(57 \%)$ ir nuovargis $(71 \%)$.

Išvados. Tyrimo metu nustatyta, kad DEB-TACE yra saugi procedūra, kurios metu pasiekiami geri gydymo rezultatai.

Adresas susirašinėti: ausra.bank@gmail.com

Gauta 2016-10-26

\section{KVIEČIAME PRENUMERUOTI "SVEIKATOS MOKSLŲ" ŽURNALĄ 2017 METAIS!}

Žurnalas "Sveikatos mokslai" (Index Copernicus, EBSCO host (Academic Search Complete), Gale (Academic OneFile), ProQuest (Ulrich's, Summon), Australia (ERA) 2012 Journal List (ERA ID 34962) skirtas visų specialybių gydytojams, slaugytojams ir kitiems specialistams, spausdina mokslinius straipsnius lietuvių, anglų kalbomis. Reikalavimai straipsniams atitinka mokslo leidiniams keliamus reikalavimus.

Žurnalas kioskuose neparduodamas.

Žurnalą, kuris leidžiamas kartą per du mėnesius, galima užsiprenumeruoti visuose Lietuvos pašto skyriuose, taip pat internetu: www.prenumeruok.It

Prenumeratos kaina nesikeičia: visiems metams - 34,75 EUR, šešiems mėnesiams - 17,37 EUR, keturiems mėnesiams - 11,58 EUR, dviem mėnesiams - 5,79 EUR.

Prenumeratos kodas: 5348.

Žurnalo autoriams straipsnių spausdinimas mokamas. 